\title{
ASSESSMENT OF TECHNICAL CONDITIONS OF BANK PROTECTION OF WATERCOURSES AND RESERVOIRS IN THE CITY OF POZNAŃ
}

\author{
Mateusz Hämmerling ${ }^{1 凶}$, Natalia Walczak ${ }^{1}$, Zbigniew Walczak², Paweł Zawadzki ${ }^{1}$ \\ ${ }^{1}$ Department of Hydraulic and Sanitary Engineering, Poznan University of Life Sciences, ul. Piatkowska 94A, \\ 60-649 Poznań \\ ${ }^{2}$ Institute of Construction and Geoengineering, Poznan University of Life Sciences, \\ ul. Piątkowska 94, 60-649 Poznań
}

\begin{abstract}
Aim of study

The aim of presented paper was to assess the technical conditions of bank protection in Poznan on following hydrotechnical structures: the Warta River, Cybina River, Malta Lake, Rusałka Lake, Bogdanka River, Sołackie Ponds and the Główna River.
\end{abstract}

\begin{abstract}
Materials and methods
Both river banks and reservoirs in cities require a specific approach. Natural processes (sediment accumulation, surface runoff, seepage) and human activity (including thoughtless acts of vandalism) force the need for continuous monitoring of banks and taking targeted measures to ensure safety in their vicinity. Properly designed, constructed and maintained reinforcements allows for long-term protection of embankments against damage and protect city residents against flooding.

In Poznań, access to the banks of the Warta River and its tributaries is unlimited. Along the waterway there are walking and cycling paths. There are water barrages on the watercourses and reservoirs are among the most attractive spots in the parks. The largest artificial reservoir, Malta Lake on the Cybina River, has a regatta course and a small beach, meaning it is under strong anthropopressure. The stands of regatta course and its technical facilities are utilised during mass events by thousands of water sports enthusiasts. From the first warm days of spring, the banks of the Warta on the downtown section are occupied by Poznan citizens. Open at 4 city beaches water equipment rentals offer kayaks and motorized boats.
\end{abstract}

\section{Results and conclusions}

The overall condition of checked reinforcements of river banks and water reservoirs should be evaluated as good. The flexible strengthening in a form of a stone coating was in the worst, though still satisfactory, condition.

Keywords: hydrotechnical structure, technical conditions, bank protection

\section{INTRODUCTION}

The safety of hydrotechnical structures, during their operation, depends on several technical and natural factors and processes that should be constantly monitored, such as:
- adequate analysis of hydrotechnical structures in operation,

- regular control of aging process of these structures (displacements, deformations, seepage),

- cyclical assessment of technical conditions, signalling any unexpected threats,

凶e-mail:mhammer@up.poznan.pl 
- monitoring changes in the upstream and downstream sites of a hydrotechnical structure,

- preventing adverse changes: maintenance, repairs or modernization.

Reinforcements are fundamental for protecting river banks, river beds and reservoirs against erosion, as well as against mechanical damage caused by large elements carried by water (floe, ice, trunks and branches, rubble). Banks exposed to erosion due to free-surface water table flow or seepage flow are most often reinforced fragments (Błażejewski et al., 1990; Novak et al., 2007; Hämmerling et al., 2018). As for water reservoirs, all banks are usually protected. Strengthening of riverbeds and banks below (and if necessary above) damming structures are used wherever increased water flow velocities are observed. However, the use of excessively long, smooth and concrete reinforcements can increase erosion below the strengthened section of a riverbed (Błażejewski et al., 1991).

The requirements that bank protections should meet are following (Novak et al., 2007; TU Delft, 2007; Bednarczyk et al., 2009):

1. Dimensions and weight of strengthening elements should prevent their movement under water pressure. Due to the highest water velocity near a hydrotechnical structure these parts of reinforcement should be more durable then the other.

2. The surface of a strengthening should be rough, because it increases flow resistance and reduces flow velocity at the bottom.

3. Maintaining mild stream expansion should ensure that there is no additional turbulence.

4. Reinforcements should be water-permeable to prevent seepage pressure and buoyancy increase.

5. The elements of bank protection should be laid on reverse filter (sand, gravel, geotextile), preventing suffosion.

Usually, to meet these requirements different methods of strengthening banks and riverbeds are applied, depending on the needs. When designing reinforcements their visibility and impact on aesthetics of rivers, canals and reservoirs (RCC 2014), as well as assessment of ecological status of watercourses has to be borne in mind (Kaluża et al., 2014). It is important to systematically inspect water management facilities, including not only damming structures, but also construction of bank protection of riverbeds and reservoirs, and flood protection linear structures.

Szpikowski and Domańska (2014) reviewed the technical conditions of selected hydrotechnical facilities located on the Parsęcia river. They found that five of the analysed objects are operative, and one ruined. According to Kledyński (2011b), most concrete structures show unintended scratches and cracks, which can pose threat to safety or operation of hydrotechnical structures, especially concrete dams. Kańka and Sołtysik (2009) during an evaluation of the technical conditions of concrete water supply noted its bad condition due to numerous leaks from side walls and transverse front wall.

Bagiński (2007) concluded that the technical conditions of Włocławek barrage does not present any direct risk. Reduction of water table level, in result of excessive erosion, can cause threat for the construction. This can be a serious problem in regard of structures stability. Hämmerling et al. (2019) presented an analysis related to bed erosion modelling using SSIM program.

\section{Types of reinforcements and their application}

Reinforcements, depending on materials, are divided into following types: technical, biotechnical and biological; and depending on susceptibility to deformation: rigid and flexible (Wołoszyn et al., 1994; Novak et al., 2007; Kita, 2007). Technical reinforcements can be made of natural and artificial materials. Biotechnical are a combination of living plants and technical materials. Biological are entirely made of living plants.

A long period of utilization of a damming structure has an increasing impact on they safety, durability and performance. Constant influence of the environment induces aging processes. Kledyński and Kuźniar (2002) observe that every construction object meets its utility functions best when it is new, and repairs allow restoring its functionality.

Concrete reinforcements are rigid elements in a form of cubes, blocks and concrete slabs, filled or openwork, used both below and above water tables. Concrete slab are placed on a layer of reverse filter or geotextile. Slots in openwork concrete plates are filled with riprap (below water table) or humus. Plates have different dimensions, assumed length depends on slab thickness, width is approx. 0.7 of the length, but not less than $1.0 \mathrm{~m}$, and thickness from $0.15 \mathrm{~m}$ up to $0.40 \mathrm{~m}$ (Wołoszyn et al., 1994). 
Stone riprap is used to strengthen lower parts of banks or for their sectional protection in areas that are particularly vulnerable to erosion. Riprap can be laid with or without hurdles, on a gravel ballast of 10 $-15 \mathrm{~cm}$ thick (Jędryka, 2007) or geotextile, sometimes it is necessary to use a combination of both (Radecki-Pawlik et al., 2018).

Gabion mattresses belong to flexible bank reinforcement, having following dimensions: width: 1.0-3.0 m, length: $2.0 \mathrm{~m} ; 3.0 \mathrm{~m} ; 4.0 \mathrm{~m} ; 5.0 \mathrm{~m} ; 6.0 \mathrm{~m}$, height: 0.17 $-0.30 \mathrm{~m}$. Gabions (from Italian gabbione - big cage, box) have a smaller section area of $1.0 \mathrm{~m} \times 1.0 \mathrm{~m}$ or $1.0 \mathrm{~m} \times 0.5 \mathrm{~m}$ and length from $1.0 \mathrm{~m}$ to $4.0 \mathrm{~m}$. Design is similar for baskets, boxes and mattresses. Basket (mattress) is filled inside with crushed stone aggregate. Galvanised wire mesh (zinc or zinc-aluminium covers, as well as PWC) are formed by welding or braiding. The size of the mesh depends on the size of the boxes and the diameter of filling aggregate. The walls of gabion baskets and grid-stone mattresses with planting are used as retaining structures for bank strengthening. The appropriate filtration materials have to be chosen for gabions so that they protect from washing elements of soil from under the baskets. Geotextile is most commonly used for this purpose. Bajkowski and Jastrzębska (2012), who conducted research on the capacity of a riverbed with baskets, set the rules for dividing a flow on gabion stepped weirs by determining the amount of filtering and water flow volume passing through a hydrotechnical structure. This approach enabled designing spillway slots with smaller widths. Further studies conducted by Bajkowski et al. (2019) allowed determining the equations of water table curve lines flowing over stepped weirs made of mesh and stone baskets.

Stone and mesh cylinders made of wire mesh have a similar construction. They have a diameter of $0.6-1.25 \mathrm{~m}$ and length of 3-10 $\mathrm{m}$. They are used to fill small breaches in banks, to build stepped weirs, barrages as well as to give foundations for other bank protections (Jędryka, 2007).

Non-wheeled fascine mattresses are made of wire bound fascines, package and load. Meshes in the upper load layer of wheeled mattresses are made of fascine fence. Mattress constructions are used for bank protection and for construction of underwater elements of longitudinal and transverse dams. They are built as panels, 4-10 m wide and $12 \mathrm{~m}$ long, or bands.
Cylinder elements have a diameter of $35-40 \mathrm{~cm}$ and a length of $6 \mathrm{~m}$, most often of coconut fibres braided with a feosynthetic mesh. They are mounted at the bottom of a slope, where they are supposed to provide light protection against erosion. They also facilitate vegetation growth in lower parts of a bank.

Biological reinforcement, such as grasses, fulfils their function by protecting the banks above medium water table in a rarely flooded zone. This is done through sowing or seedling (Żelazo and Popek, 2014). These slopes are sowed, where water flow velocity does not exceed $1.0 \mathrm{~m} \times \mathrm{s}^{-1}$. Biological reinforcements also include shrubs and trees, whose root systems strengthen the ground, preventing its washing, while the parts above the ground decrease flow velocity and provide shading, which also reduces the intensity of vegetation development in the riverbed (Tymiński and Kałuża, 2012; Tymiński and Kałuża, 2013).

The aim of study was to use the method of assessing technical conditions of reinforcements developed by Zawadzki (2005) to examine riverbeds, reservoirs and ponds reinforcements in urban areas. The presented method is an alternative to the commonly used 10-point assessment used by KZGW. This method allows less experienced engineers to analyse technical conditions of river reinforcements.

\section{RESEARCH METHODOLOGY}

Technical conditions of reinforcements were assessed through an on-site verification and photographic documentation taken in the following facilities: the Warta River, the Cybina River, Malta Lake, Rusałka Lake, the Bogdanka River, Sołackie Ponds and the Główna River. It is possible basing on an available data analysis to predict changes in technical conditions and their pace over time. Utilizing historical images of the analysed structure from previous years allows assessing the consequences following a defect and deterioration rate over a longer period of operating. Due to the fact that the authors have photographic documentation covering operating period, they could determine the technical conditions of bank protections. Also, such information is sufficient to assess change rate of technical conditions of given banks. The tests were performed with the method described by Zawadzki 
(2005) with subsequent modifications introduced by Walczak et al. (2017) regarding reinforcements in the lower and upper sites of the hydrotechnical structure and on the banks of reservoirs and watercourses. It was also employed, among others, by Dąbkowski and Jędryka (2014), Tarnawski and Michalec (2007), Michalca (2013), Michalca et al. (2017). Random spot that during eight years of operating (and twice draining the water in Malta Lake) at least once it underwent modernization and repair was selected for assessment. These are sites, which according to subjective assess- ment of the object's owner have significantly deteriorated since the last repair.

The conditions of both flexible and rigid reinforcements, as well as of their couplings were determined by the method employed by Zawadzki (2005) and modified by Walczak et al. (2017). The tests were performed on a scale of 1 to 5 , which took into account the occurrence and intensity of adverse or harmful processes. In this scale (Table 1), 5 indicates - very good (no adverse processes), 4 - good, 3 - satisfactory, 2 - unsatisfactory, 1 - bad (strongly adverse processes).

Table 1. Criteria for assessing technical conditions of reinforcements (Walczak et al., 2017)

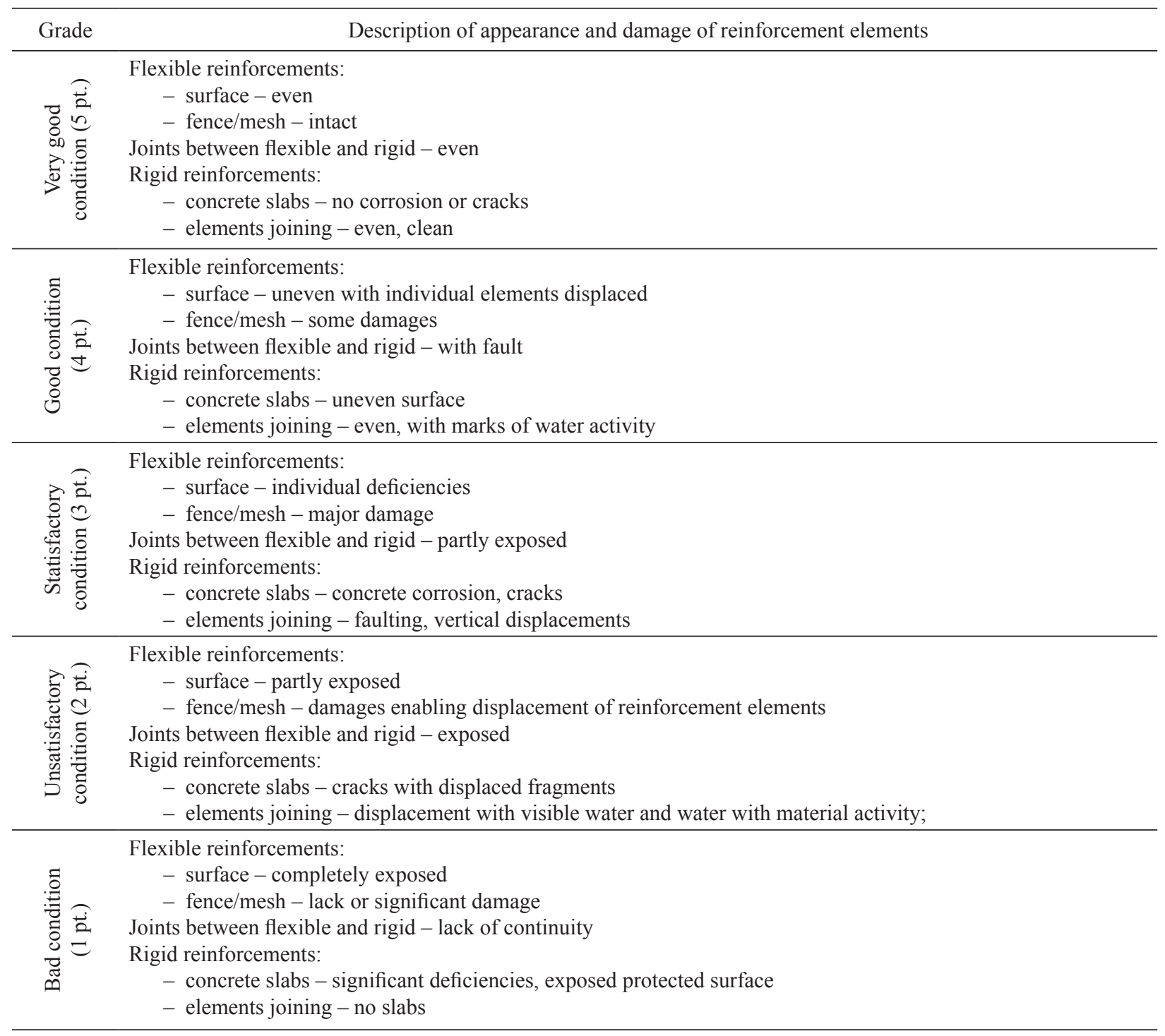




\section{Warta River}

The Warta flows through Poznań from the southern to northern reaches of the city, over a section of $15 \mathrm{~km}$, i.e. from $\mathrm{km} 251+000$ to $\mathrm{km} 236+000$ of its course. On a section of approx. $5 \mathrm{~km}$ from the Przemysła I bridge ( $\mathrm{km} \mathrm{246)}$ to a railway bridge on the Poznań-Warsaw route $(\mathrm{km} 241+000)$ the banks of the river are strengthened. The cross-section of the riverbed on this section is designed as two-part, with a bottom width of $35 \mathrm{~m}$, a slope of banks 1:3, an elevation of the upper edge of the slope above an average annual water level is $0.5 \mathrm{~m}$. The floodplains are designed with $1: 1000$ transverse gradient towards the river, limited by slopes with $1: 2$ gradient. The width of the great water varies from $245 \mathrm{~m}$ at the Roch bridge to $104 \mathrm{~m}$ near the Mieszko I bridge (Przedwojski et al., 2007).

The reinforcements of the Warta embankments on the urban section of Poznan include concrete slabs supported from below with concrete elements (drainage dowel, dovetail), with a palisade and stone covering below (see: Fig. 1). Some fragments of reinforcement (especially the flexible) built about 50 years ago are in worse condition, however, they received a good grade -4 .

Concrete slabs (see: Fig. 2 and 3) are cracked in some places or surface corrosion of concrete has advanced (grade: 3 ), along the concrete defects are visible (grade: 2).
Fig. 1. View of bank protections of the Warta River on the Poznań section

Photo by P. Zawadzki

Fig. 2. Scratches (a) and cracks (b) of rigid concrete slab

Photo by P. Zawadzki
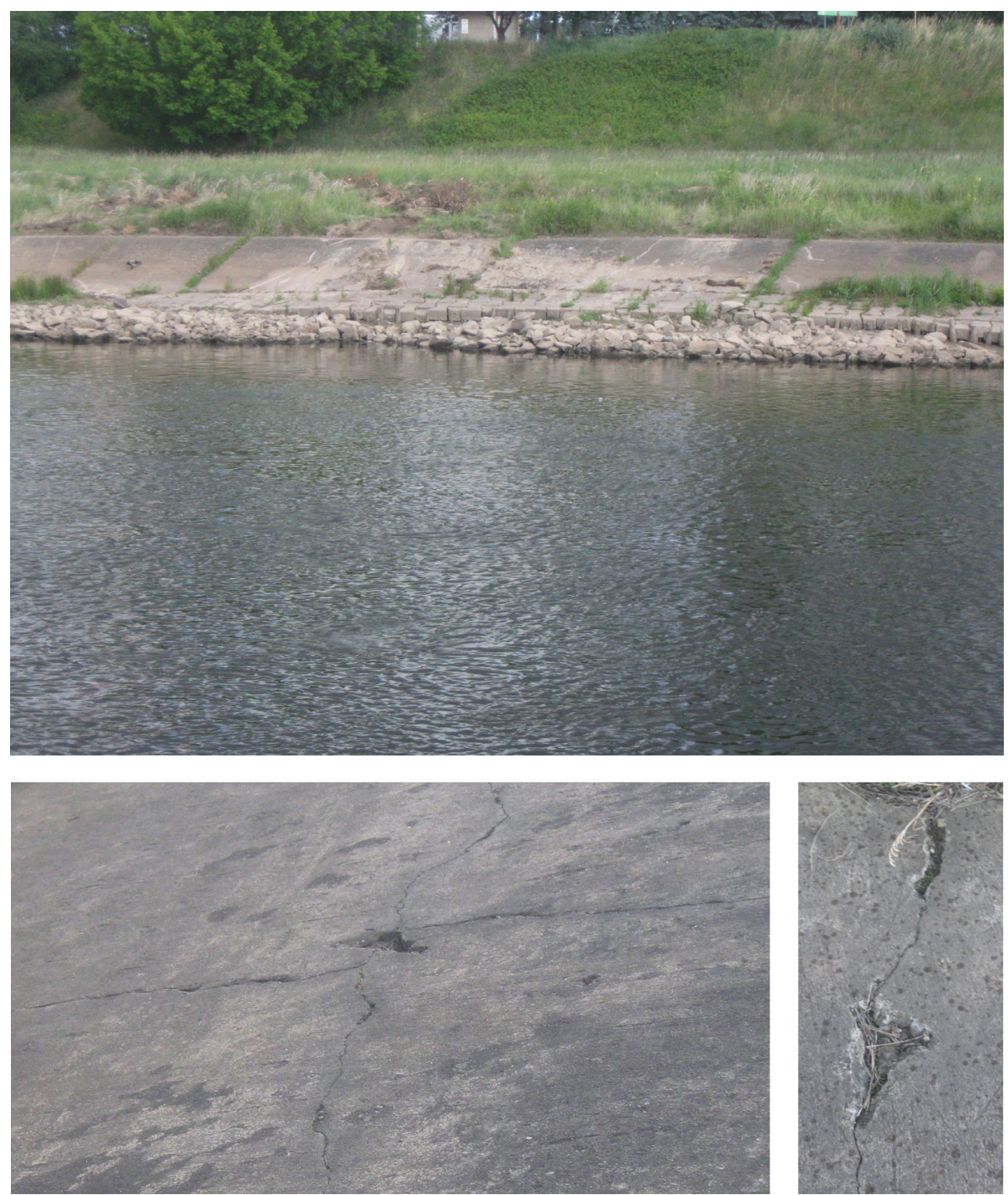

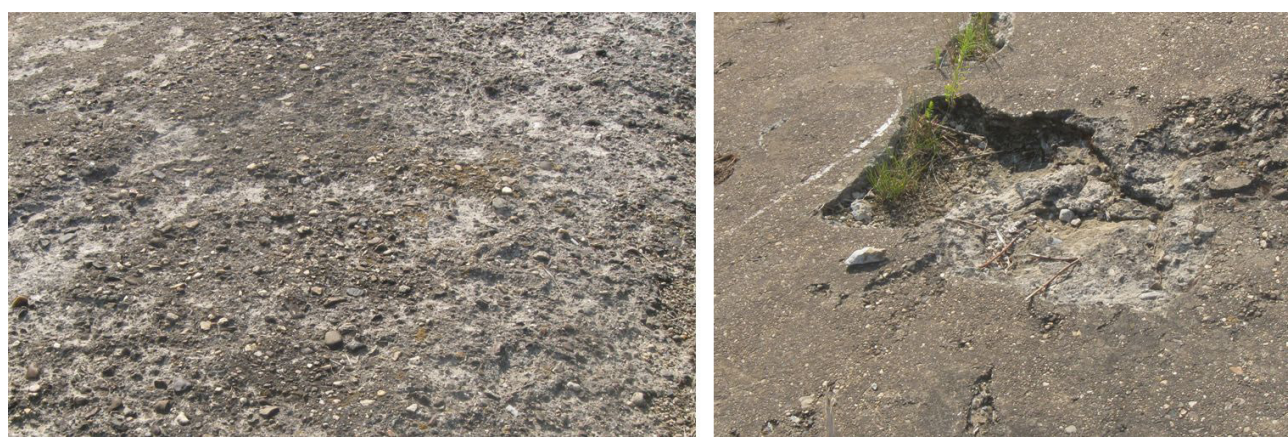

Fig. 3. Surface corrosion (a) and cracks (b) of concrete slab

Photo by P. Zawadzki
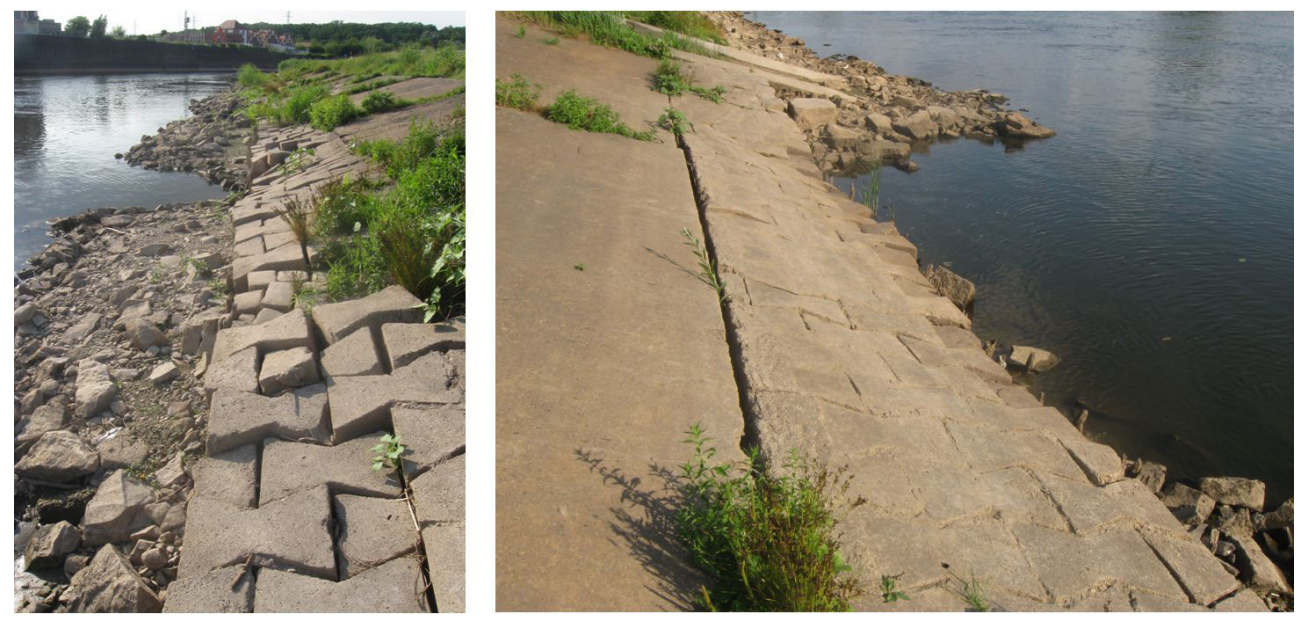

Fig. 4. Unsatisfactory or poor flexible strengthening on the Warta

Photo by P. Zawadzki

On selected sections of the river (see: Fig. 4), unsatisfactory or poor conditions of flexible reinforcements were observed: concrete dowels subsided and displaced (grade: 2), and below them the surface of a protected embankment and the riverbed is exposed due to a lack of stone coating (grade: 1). Reinforcement surface is uneven, the gaps are expanding between individual elements as well as between both rigid and flexible strengthening.

Proceeding deterioration and stone losses in the flexible strengthening were caused, in particular, by an intense movement of tourist ships and motor-powered boats in 2016 and 2017. During this period, water levels remained below the lower edge of the riprap, i.e. at a level where banks were not reinforced. An additional factor affecting the deteriorating con- ditions of reinforcements is an intensive exploitation of this area by the citizens for recreational purposes.

\section{Cybina River}

The Cybina River as its right tributary joins the Warta within Poznań, at $242+700 \mathrm{~km}$. Its total length is $43 \mathrm{~km}$ with catchment area of $186.5 \mathrm{~km}^{2}$. In the mouth section (9 km inside Poznań), Cybina flows through four artificial ponds: Antoninek, Młyński, Browarny, Olszak and across Malta Lake.

The banks of the river are covered by grasses, and technical reinforcements were built only in the vicinity of damming structures.

Before the modernization of the lower site of the Antoninek weir banks were protected by a loose stone coating. This enabled uncovering and bank erosion by 
Hämmerling, M., Walczak, N., Walczak, Z., Zawadzki, P. (2019). Assessment of technical conditions of bank protection of watercourses and reservoirs in the city of Poznań. Acta Sci. Pol., Formatio Circumiectus, 18 (3), 3-17. DOI: http://dx.doi.org/10.15576/ASP.FC/2019.18.3.3

moving stones, which could cause instability of the structure (grade 2).

After modernization, the lower site was strengthened with gabions that secure the stability of bed and slopes of the riverbed, especially the left bank (grade 5).
The Olszak weir (see: Fig. 7) was gradually modernized by placing granite cubes with concrete mortar on a slope of the upper site (grade 3 ). Due to the lack of abutment, the lower parts of the escarpment subside

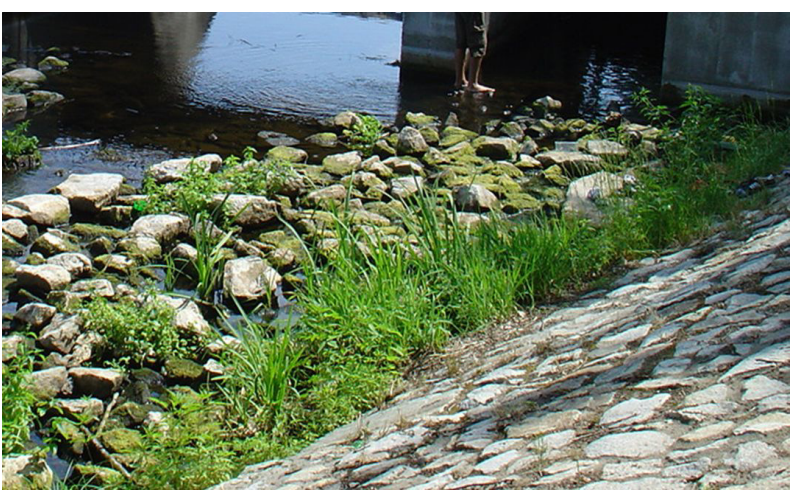

Fig. 5. Lower site of the Antoninek weir; a) view before (2005), b) after modernization (2009)

Photo by P. Zawadzki
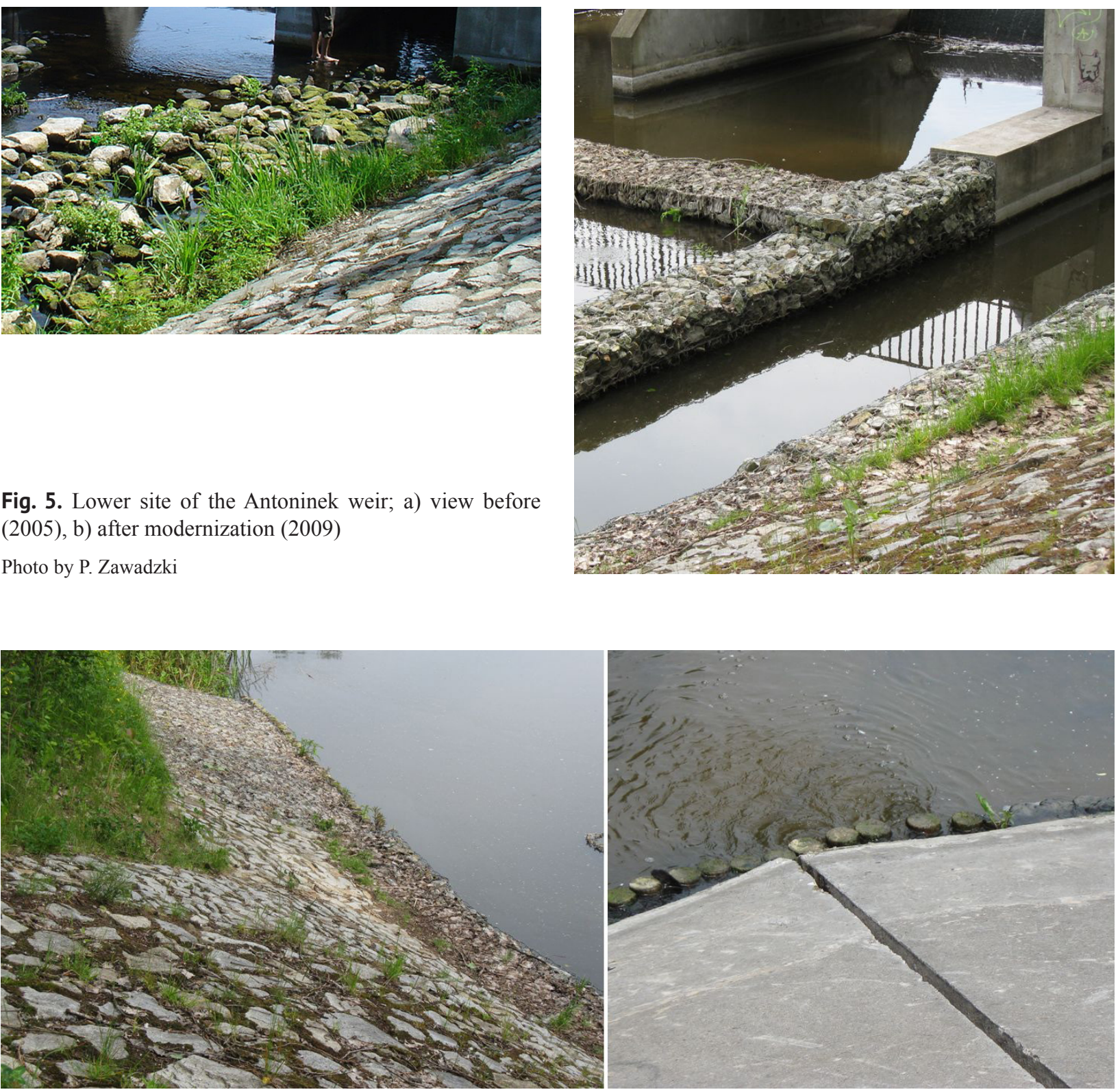

Fig. 6. Bank protection of the Cybina below the Antoninek weir: a) stone reinforcements, b) concrete reinforcements Photo by P. Zawadzki 


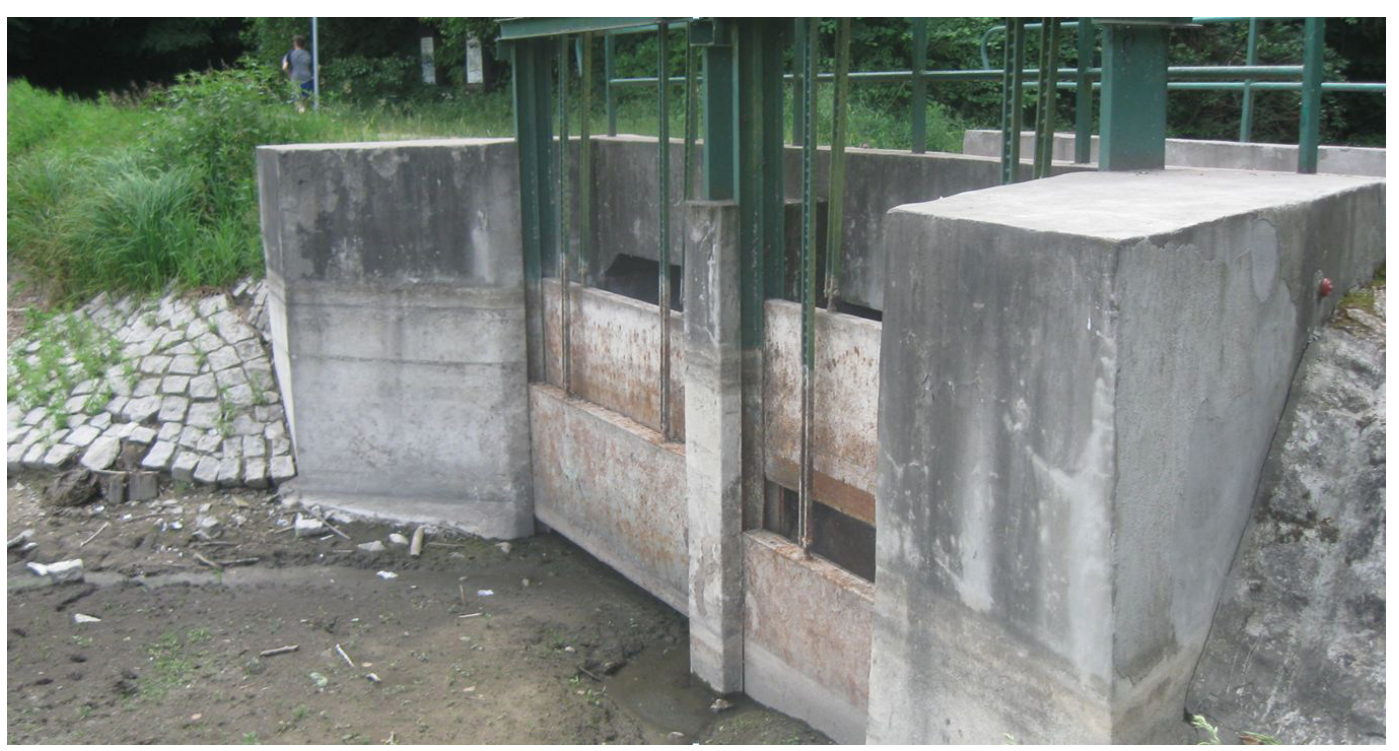

Fig. 7. Upper reinforcement of the Olszak weir

Photo by P. Zawadzki

\section{Malta Lake}

The surface area of the Malta Lake is $0.64 \mathrm{~km}^{2}$, with $2.2 \mathrm{~km}$ of width and $0.46 \mathrm{~km}$ of length. Due to its location and (recreational-aesthetic) nature, the reservoir works under conditions of strong anthropopressure. Flexible (stone coating) and biological (grass seeding and fascine fence) elements were used to strengthen the Malta Lake banks. The escarpment in the immediate vicinity of the damming structure (weir) was strengthened with hexagonal concrete and openwork slabs (see: Fig. 8). During sport competitions water can strongly affect loose stone coating, causing its subsidence. The technical conditions of the banks in the vicinity of the discharge-spillway structure were assessed as satisfactory (grade 3 ).

The technical conditions of banks in municipal reservoirs may deteriorate as a result of human activity, especially in the summer period, when citizens in large numbers take the opportunity to relax by the water. This is a common and dangerous. During reservoir exploitation the escarpments are flooded, but once every four years the reservoir is emptied (for maintenance of the bottom of reservoir), exposing the area to frost.

After draining the water from the reservoir (see: Fig. 9a) reinforcement conditions are assessed and only those fragments that have been seriously damaged undergo necessary repairs.

Based on photographic documentation, it can be observed that after a year of lake exploitation vegetation has overgrown the supplemented broken stone (see: Fig. 9b). Vegetation additionally protects the banks against undulation (grade 4).

The state of reinforcements of the right bank of the Malta Lake is shown in Fig. 10. In this zone it is possible for shrub vegetation to grow across a larger area due to a gentler banks slope. The use of fascine fences improved the technical conditions of the escarpment, because the fence made it impossible to move the broken stone towards the bottom (grade 4).

Access to the banks of Malta Lake is not limited in any way, therefore they are exposed to anthropogenic deterioration (see: Fig. 11), like throwing stone elements into the water, or in winter on ice.

Other exploiting actions take place at the inlet part of the reservoir, resulting from the intensive inflow and accumulation of mineral and organic debris. The banks are reinforced with concrete slabs and stone covering, and above the slope it is covered with grass. The technical conditions of bank protection are good (grade 4). 

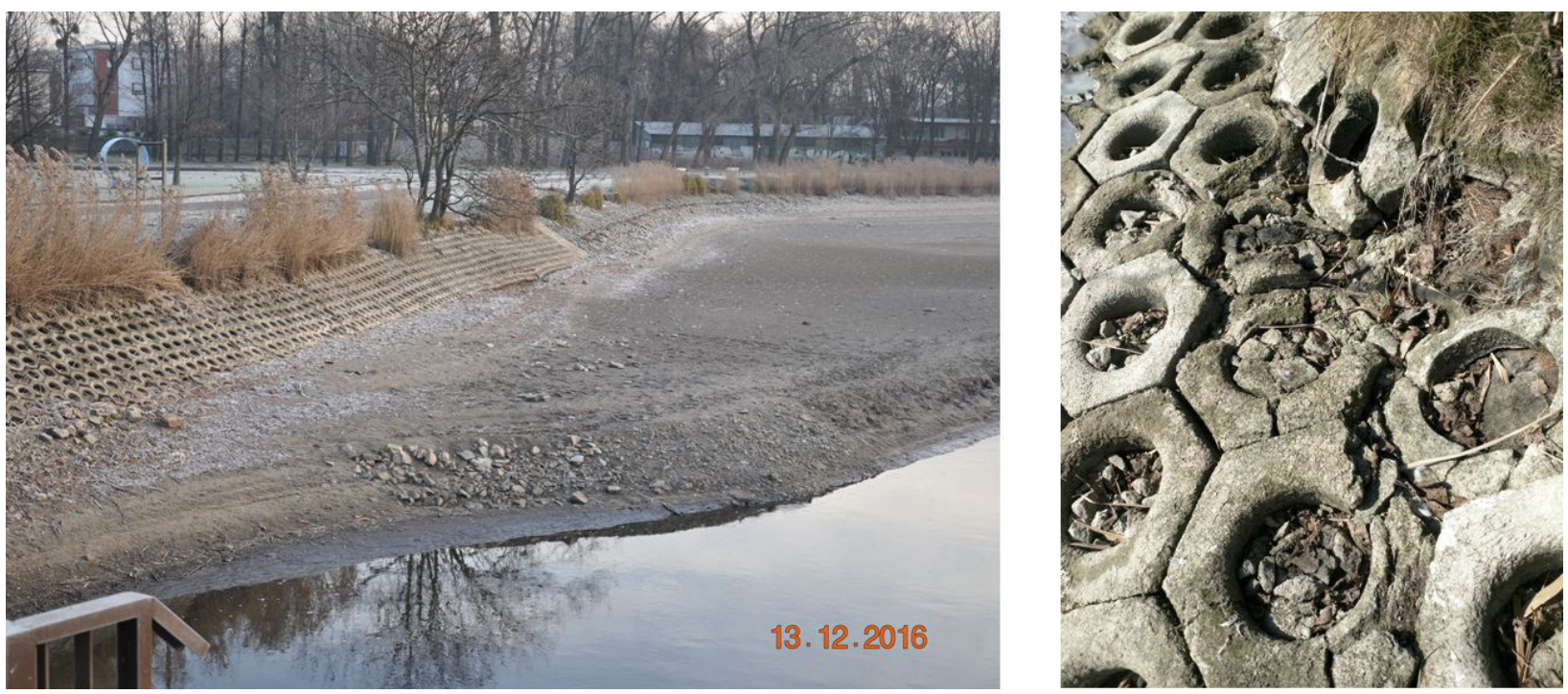

Fig. 8. Right bank of the Malta Lake: a) general view of reinforcements, b) view of structural elements of reinforcement Photo by P. Zawadzki
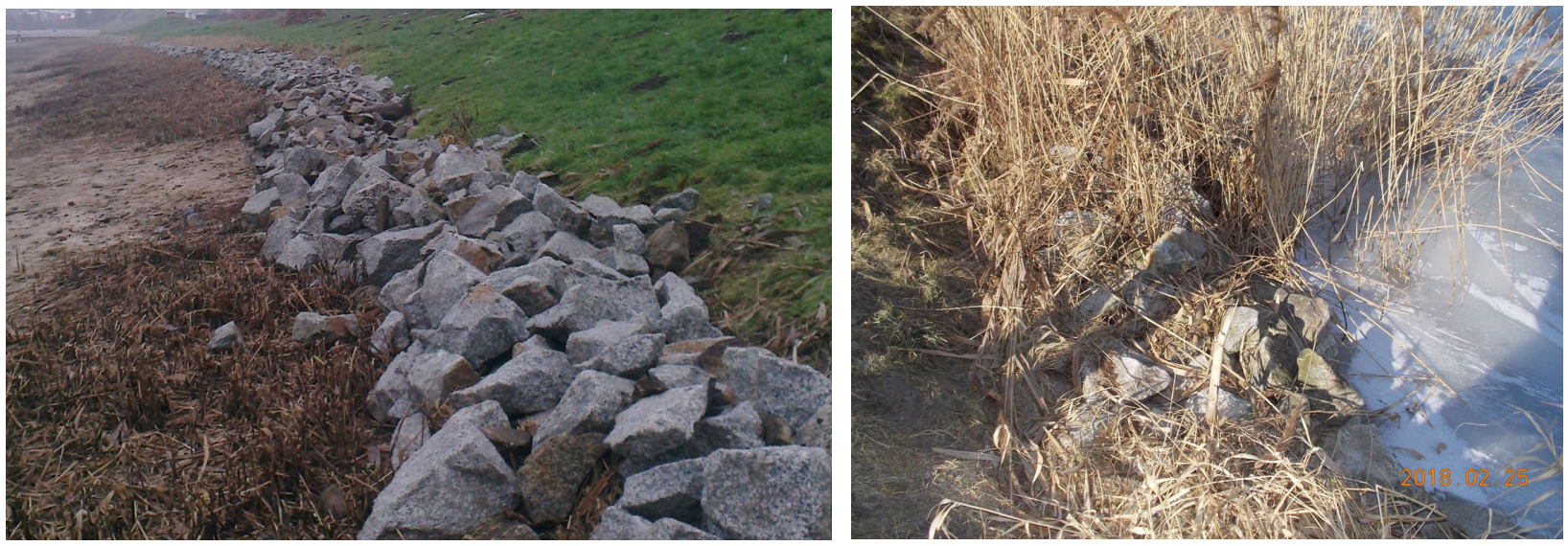

Fig. 9. View of the bank protection at the bottom of the reinforced escarpment with stone coating a) after the reservoir has been emptied b) after one year of exploitation

Photo by P. Zawadzki

\section{Bogdanka River and Sołackie Ponds}

The Bogdanka River is a $9.3 \mathrm{~km}$ long left-bank tributary of the Warta taht runs entirely within the boundaries of Poznań. Strzeszyńskie Lake is considered to be the source section, after setting off from which the river flows through two Strzeszyńskie Ponds, Rusałka Lake and ponds in Solacki Park. The river and its tributaries (left-bank Wierzbak Stream and right-bank Saganka Stream) is used to drain out rainwater from the north-west part of the city. The Bogdanka is com- pletely regulated, and on the final section, about $2 \mathrm{~km}$, it flows through an underground canal that belongs to the municipal sewage system. The banks of the river in the upper part of its catchment are covered with grasses and aquatic vegetation. The same type of reinforcements can be found around Rusałka Lake and ponds in the Sołacki Park. In the vicinity of weirs and spillways and a culvert maintaining damming levels (see: Fig. 12), escarpments were reinforced with granite blocks with concrete joints or slabs on a concrete binder (grade 4). 
Hämmerling, M., Walczak, N., Walczak, Z., Zawadzki, P. (2019). Assessment of technical conditions of bank protection of watercourses and reservoirs in the city of Poznań. Acta Sci. Pol., Formatio Circumiectus, 18 (3), 3-17. DOI: http://dx.doi.org/10.15576/ASP.FC/2019.18.3.3
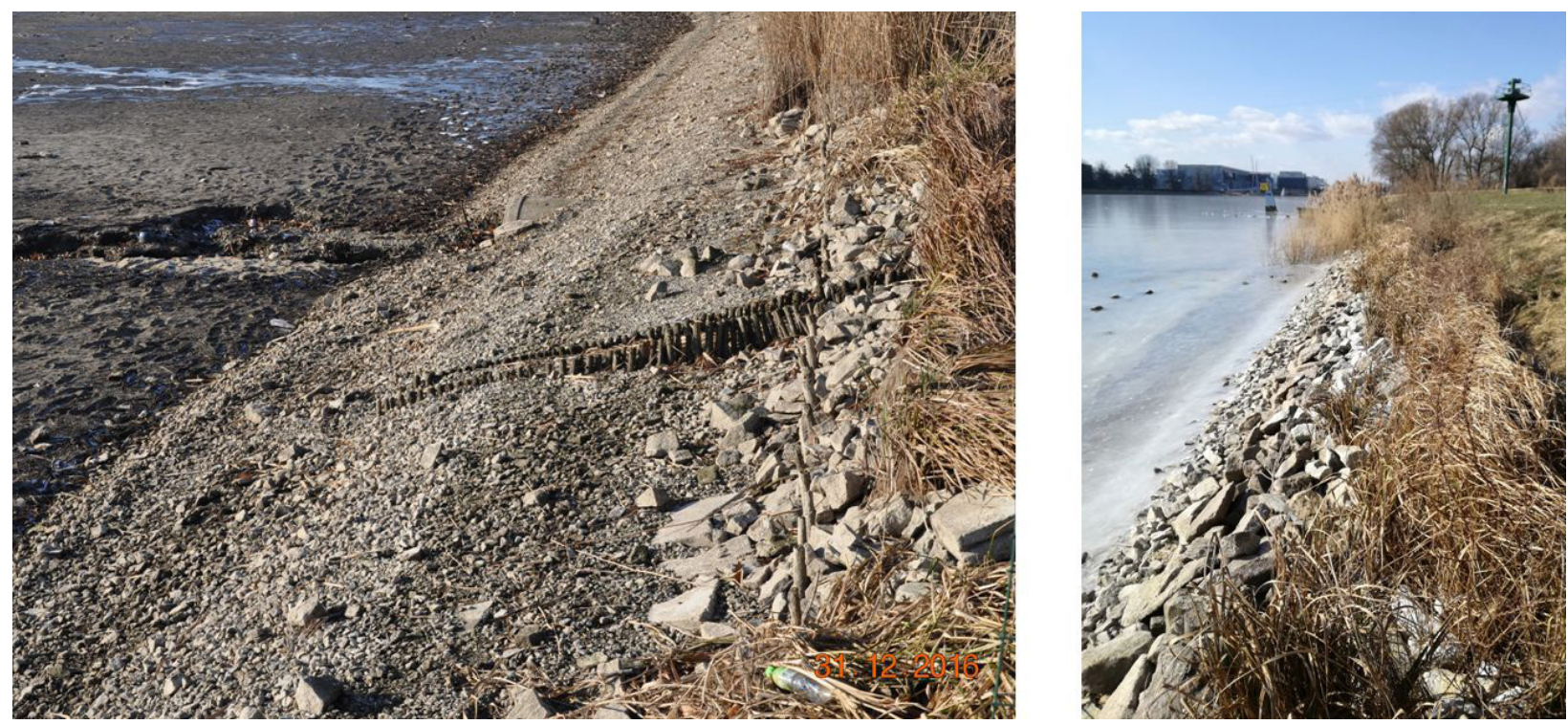

Fig. 10. Right bank reinforcement of the Malta Lake: a) during the emptying of the reservoir, b) in the winter Photo by P. Zawadzki
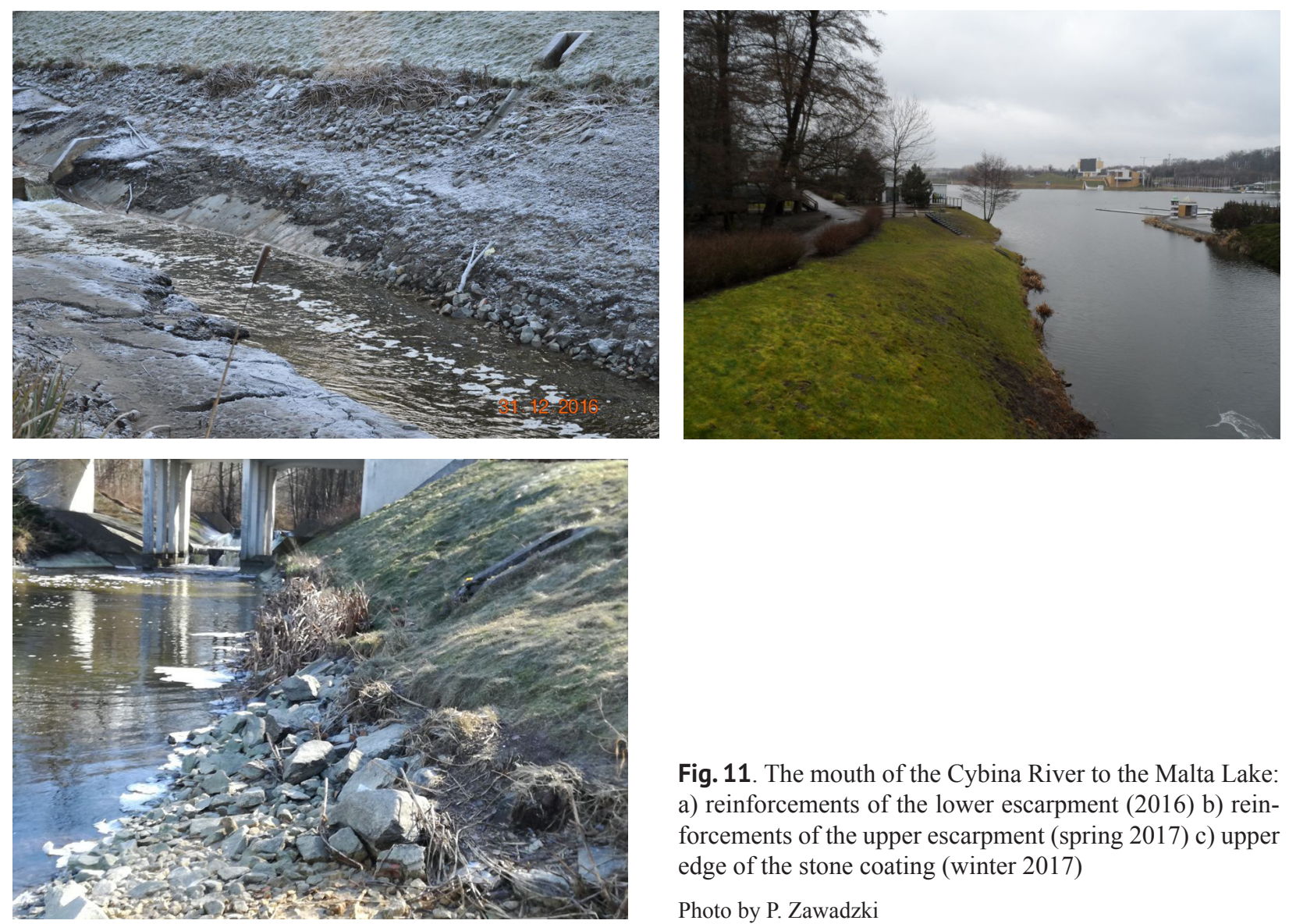

Fig. 11. The mouth of the Cybina River to the Malta Lake: a) reinforcements of the lower escarpment (2016) b) reinforcements of the upper escarpment (spring 2017) c) upper edge of the stone coating (winter 2017)

Photo by P. Zawadzki 


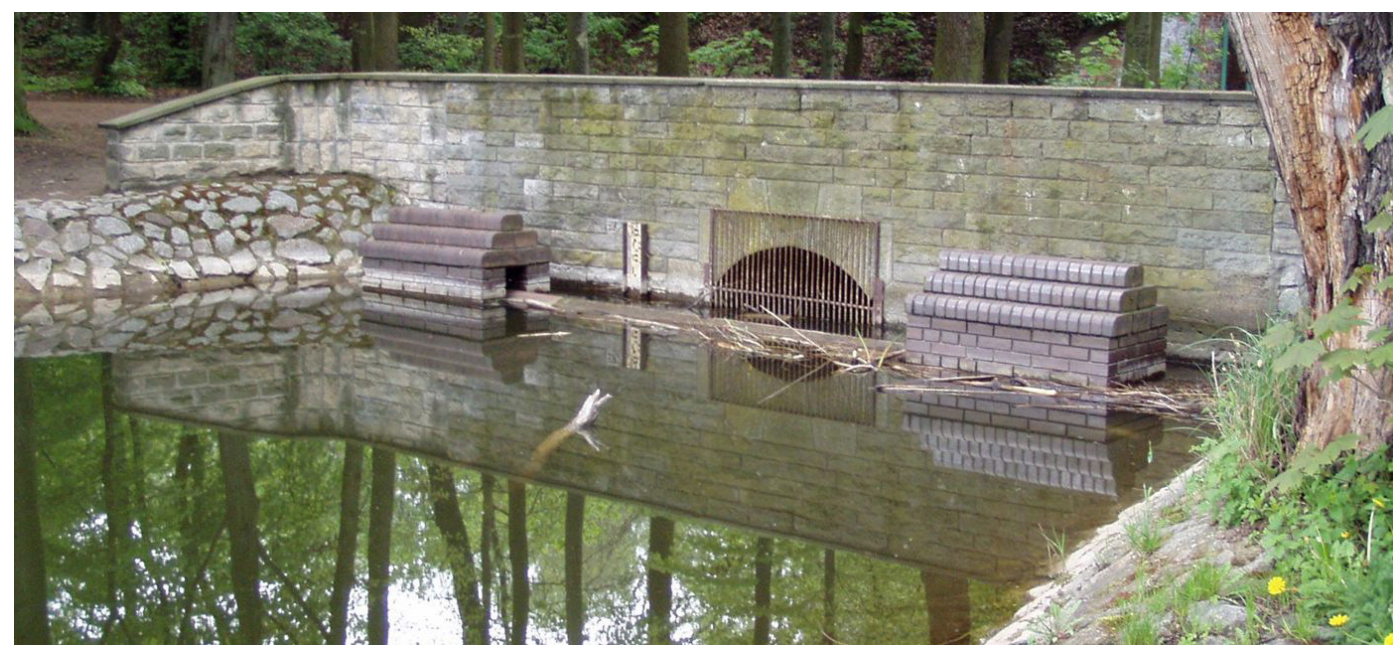

Fig. 12. Barrage of the Rusałka Lake

Photo by P. Zawadzki

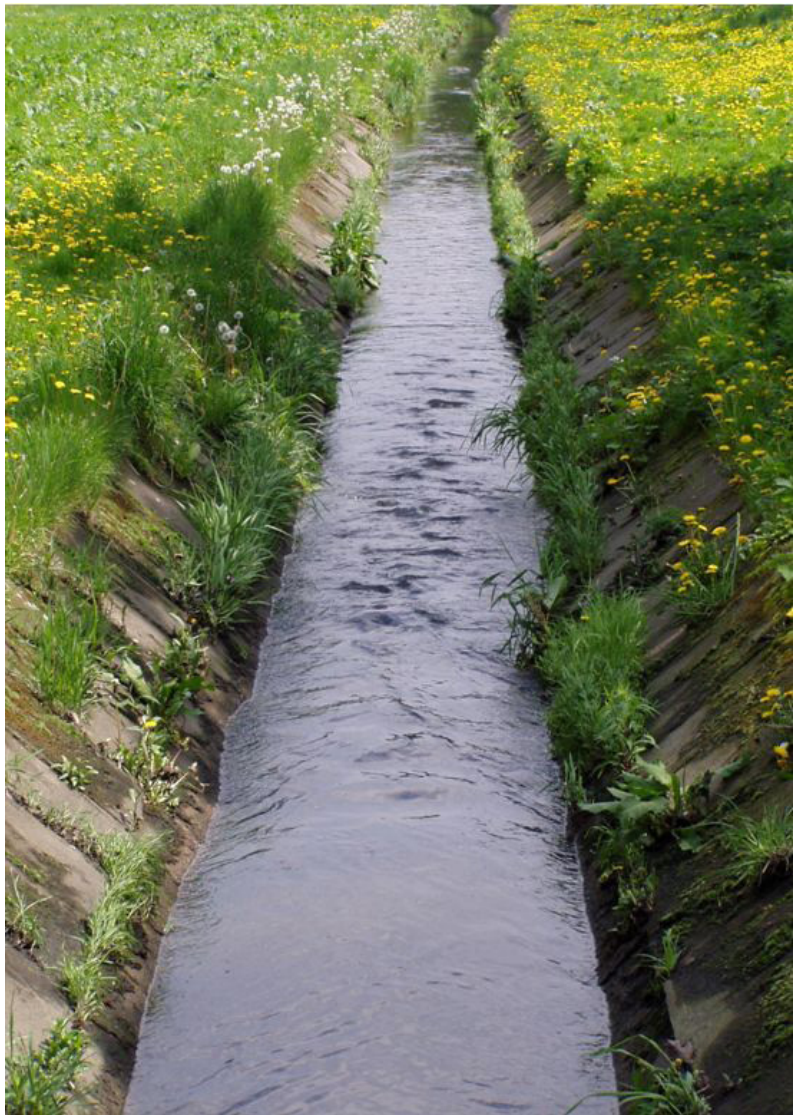

Fig. 13. Strengthening of banks of the Bogdanka below Nad Wierzbakiem Street (Wodiczka Park)

Photo by P. Zawadzki
On the watercourse section below Nad Wierzbakiem Street (after being joined by tributaries), banks were strengthened with openwork concrete slabs, which were overgrown with grassy vegetation, this is particularly visible at joints of the slabs (grade 3). Immediately, due to the adopted banks slope, torrential rain and a significant increase in intensity and velocity of water flow have led to higher instability of individual slabs. It seems that this has been stopped by development of vegetation.

\section{The Gtówna river}

The Główna River is a right tributary of the Warta. The river is about $46 \mathrm{~km}$ long with a section of $3.5 \mathrm{~km}$ running through Poznań. Up to the 1950 s, two water mills were operating on the Główna River in Poznań: Nadolnik and Górnik. Currently, only the stepped weirs at damming sites regulate the rivercourse. The banks of Główna on the urban section are covered by grass, but only near bridge crossings its escarpments are reinforced with concrete slabs. Due to many years of exploitation the banks have become naturally overgrown, and the current vegetation does not limit flow capacity of the riverbed (grade: 3 ). The authors suggest that there is a possibility of restoring damming for recreational purposes on the studied section of the Główna. 

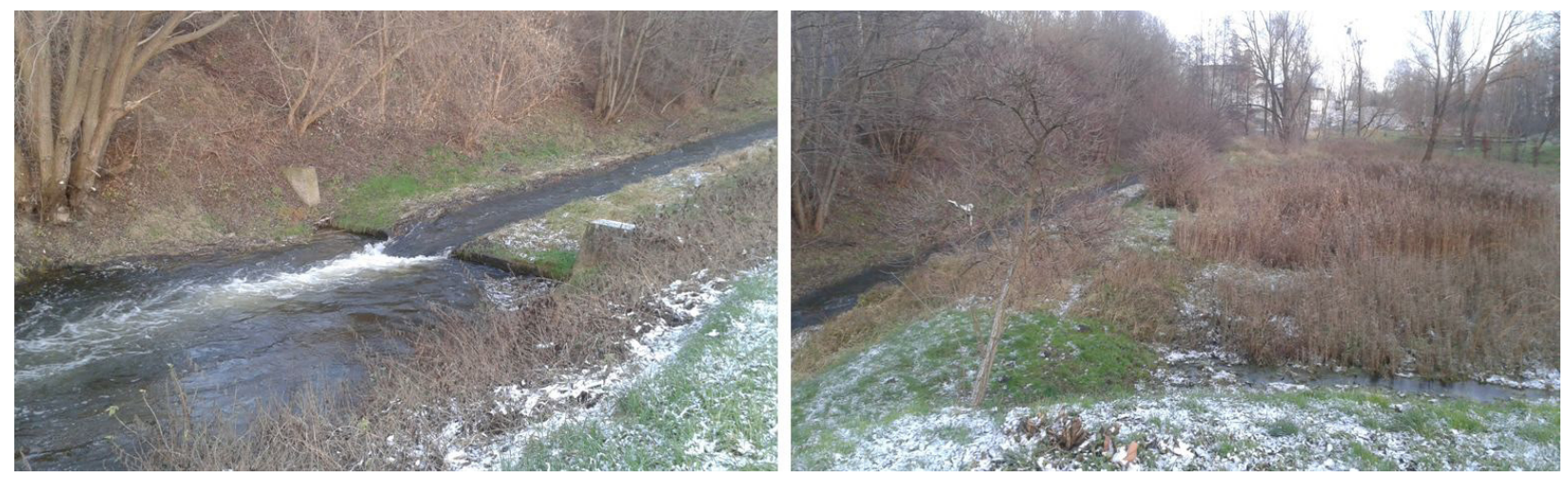

Fig. 14. The Główna River - regulatory step in the place of the former Nadolnik mill and the pond bowl

Photo by P. Zawadzki

\section{DISCUSSION}

The analysis and assessment of technical conditions of hydrotechnical structures carried out in this paper was required both by the provisions of the Water Law and the Construction Law. Kledyński (2011a) claims that in Poland there is no coherent dam control system - being more closely attached to water structures class division and by ownership criteria. There is no central database on technical conditions and safety of hydrotechnical facilities that could be used to analyse changes in technical parameters of water damming structures.

Gąsowska and Urbański (2013), based on field observations and photographic documentation, assessed the technical condition of the reservoir before and after modernization on the Gnida River in Leźnica Wielka. High water led to overflowing the crown of a damming structure causing damage of the barrage and the left upstream escarpment of the reservoir, as well as cracking and displacing of openwork concrete slabs. Due to the limitation of the possibility of damming water in the reservior, it had to be rebuilt. The construction works improved the technical condition of the spillway, the front dam and the left-side barrage and enabled all functions of the reservoir to be fully restored.

Jastrzebska and Urbański (2010) for assessing the technical conditions of both reinforcements and hydrotechnical facilities had analysed an inventory of individual elements of a structure, measured changes and identified cracks, scratches, leaks and material losses. An analysis of the technical condition of the reinforcements below the Sosnówek weir on the Augu- stowski Canal has shown insufficient bank protection that is ineffective against erosion. Mostly the fascine elements were damaged.

A very detailed analysis of the technical conditions of canals and ditches in the Zagórów polder was carried out by Bykowski et al. (2014). It included direct measurements of drainage facilities parameters located on the polder's area and assessment of facelities technical conditions according to the modified Kacy and Interewicz methodology. The authors of the study reported that $19.2 \%$ of ditches and canals are in an acceptable condition, and $80.8 \%$ in an unacceptable condition. The Goślinka, Trojanka and Struga Owińska watercourses were examined by Liberacki and Olejniczak (2013). They indicated that a total of as much as $96.7 \%$ of water and drainage facilities, including 24 buildings and 11.58 $\mathrm{km}$ of selected ditches, require urgent modernization.

Tarnawski and Michalec (2017) using the Zawadzki method (2005) assessed the technical state of a weir of a dam on Zesławice reservoirs in two phases of diagnostics: in the first, the technical condition of the examined structure without an initial instruction was determined; in the second - after briefing. Initiated studies on the impact of personal competence in conducting technical assessment of water structures on the result of actual assessment proved insufficient knowledge and lack of experience in inspecting conditions of hydrotechnical structures. This also induces underestimating of assessment results.

Very important aspects of protection analyses are studies of riverbed and catchment capacity, which were conducted by Walczak et al. (2018) and Laks et al. 
(2017). This type of research allows determining the impact of vegetation on areas adjacent to rivers with high flood risk and obtaining accurate knowledge of vegetation growth rate, which can help in rational management, capacity maintenance and good ecological conditions of natural river valleys (Kałuża et al., 2014).

Authors of the mentioned studies used very different methodologies. They employed methodologies from measuring changes in identification of cracks, scratches, leaks, material losses (Jastrzebska and Urbański, 2010) through the modified method of Kacy and Interewicz (1991), according to which a device is working if basic parameters do not exceed limit values, and to Zawadzki's method (Tarnawski and Michalec, 2017). This allows more detailed and accurate analyses. Assignment of detailed descriptions and characteristics of elements of reinforcements to individual assessments makes providing correct evaluation easier.

\section{SUMMARY}

Rivers in Poznan are regulated with biological strengthening used over a considerable length of their course. Technical bank reinforcements were utilised primarily, where increased water flow velocities (near dams, spillways or bridges) can be expected, or where a river valley has been narrowed and any changes in the course of a riverbed (reinforced section of the Warta) could be allowed. The overall condition of examined reinforcements of river banks and water reservoirs should be assessed as good. Flexible reinforcements, especially stone coating, proved worse conditions, but still satisfactory. Both on the banks of Warta River and Malta Lake covering deficiencies can be observed as mainly caused by human activity: increase in tourist traffic on the Warta leading to undulation, stones pulled out from reinforcements and thrown back into the water. Such destructive human impact on the condition of flexible bank protections should be taken into account when designing for urban agglomerations.

With all certainty, the problem of bank protection requires a new perspective, both from the technical and ecological point of view. Solutions that would meet the real needs in the field of regulation would also meet the conditions necessary for the development of the environment, although sometimes it is expensive and difficult to implement.

\section{REFERENCES}

Bagiński, L. (2007). Wybrane problemy stanu bezpieczeństwa stopnia Wodnego Włocławek. Nauka Przyroda Technologie, 1(2), 12.

Bajkowski, S., Jastrzebska, U. (2012). Badanie wpływu kształtu progu gabionowego na podział przepływu. Przegląd Naukowy. Inżynieria i Kształtowanie Środowiska, 21(4[58]).

Bajkowski, S., Tzminska, A., Piatek, S. (2019). Zredukowane współrzędne obrysu strumienia na trapezowym progu przepuszczalnym z przelewem o ostrej krawędzi na skarpie górnej. Przegląd Naukowy. Inżynieria i Kształtowanie Środowiska, 28(1[83]).

Bednarczyk, S. Bolt A., Mackiewicz S. (2009). Stateczność oraz bezpieczeństwo jazów i zapór. Gdańsk: Wydawnictwo Politechniki Gdańskiej.

Błażejewski, R., Lewandowski J.B., Zawadzki P. (1990). Optymalne projektowanie umocnień poniżej budowli wodnomelioracyjnych. Zeszyty Naukowe AR w Krakowie. Kraków: Wyd. AR. 249, 25-264.

Błażejewski, R., Wałęska R., Zawadzki P. (1991). Wpływ długości i rodzaju umocnienia jazu melioracyjnego typu J na wielkość rozmyć miejscowych. Roczniki AR w Poznaniu. Poznań: Wyd. AR. CCXXIV, 3-16.

Bykowski, J., Przybyła, C., Napierała, M., Mrozik, K., Pęciak, A. (2014). Ocena stanu technicznego infrastruktury wodno-melioracyjnej na polderze Zagórów. Inżynieria Ekologiczna, 39, 42-50.

Dąbkowski, Sz.L., Jędryka, E. (2014). Podsumowanie oceny stanu technicznego budowli, ocena stanu bezpieczeństwa, zalecenia pokontrolne. Prezentacja, Instytut Technologiczno-Przyrodniczy Falenty, http://www.itep.edu. pl/nauka/konferencje/ko20140624/Wyklad\%20V.pdf.

Hämmerling, M., Walczak, N., Kałuża, T., Oliskiewicz -Krzywicka, A. (2018). Operational problems of selecteds elements of the Dobrzyca barrage on the Głomia river. Rocznik Ochrona Środowiska, 20,163-183.

Hämmerling, M., Walczak, N., Nowak, A., Mazur, R., Chmist, J. (2019). Modelling Velocity Distributions and River Bed Changes Using Computer Code SSIIM below Sills Stabilizing the Riverbed. Polish Journal of Environmental Studies, 28(3).

Jastrzebska, U., Urbanski, J. (2010). Stan techniczny jazu Sosnówek na Kanale Augustowskim. Przegląd Naukowy. Inżynieria i Kształtowanie Środowiska, 19(4[50]).

Gasowska, M., Urbański, J. (2013) Odbudowa zbiornika retencyjnego na rzece Gnidzie w Leźnicy Wielkiej. Przegląd Naukowy. Inżynieria i Kształtowanie Środowiska, 22(1[59]). 
Hämmerling, M., Walczak, N., Walczak, Z., Zawadzki, P. (2019). Assessment of technical conditions of bank protection of watercourses and reservoirs in the city of Poznań. Acta Sci. Pol., Formatio Circumiectus, 18 (3), 3-17. DOI: http://dx.doi.org/10.15576/ASP.FC/2019.18.3.3

Jędryka, E. (2007), Budowle wodne z naturalnych materiałów, Woda - Środowiska - Obszary Wiejskie, 7, 2b(21), $55-74$.

Kaca, E., Interewicz, A. (1991). Metodyka oceny stanu technicznego urządzeń melioracyjnych w systemach nawodnień podsiąkowych. In Mat. Konf. Nauk.” Postęp w projektowaniu i eksploatacji systemów nawodnień podsiąkowych". Warszawa: Wyd. SGGW. 90-99

Kańka, S., Sołytsik, R. (2009). Przykłady napraw i wzmocnień budowli hydrotechnicznych wykonywanych w technologii betonowania pod wodą. XXVI Konferencja Naukowo-Techniczna Awarie Budowlane, Międzyzdroje, 819-826.

Kałuża, T., Pietruczuk, K., Szoszkiewicz, K., Tymiński, T. (2014). Assessment and Classification of the Ecological Status of Rivers in Poland According to the Requirements of the Water Framework Directive. Wasserwirtschaft, 104, 12, 24-29.

Kledyński, Z., Kuźniar, P. (2002). Model trwałości obiektów biotechnicznych. III Konferencja naukowa nt. Bezpieczeństwa i trwałości budowli wodnych, Zeszyty Naukowe Akademii Rolniczej we Wrocławie, Wrocław, 437.

Kledyński, Z. (2011a). Monitoring i diagnostyka budowli hydrotechnicznych, Nowoczesne Budownictwo Inżynieryjne, Marzec-Kwiecień, 1, 54-61.

Kledyński, Z. (2011b). Monitoring i diagnostyka budowli hydrotechnicznych, Nowoczesne Budownictwo Inżynieryjne, Maj-Czerwiec, 2, 36-38.

Laks, I., Szoszkiewicz, K., Kałuża, T. (2017). Analysis of in situ water velocity distributions in the lowland river floodplain covered by grassland and reed marsh habitats-a case study of the bypass channel of Warta River (Western Poland). Journal of Hydrology and Hydromechanics, 65(4), 325-332.

Liberacki, D., Olejniczak, M. (2013). Ocena potrzeb renowacji i modernizacji urządzeń wodno-melioracyjnych zlokalizowanych na wybranych ciekach w Puszczy Zielonka. Rocznik Ochrony Środowiska (Annual Set of Environment Protection), 15, 930-943.

Michalec, B. (2013). Ocena stanu technicznego jazu w Bieńczycach na rzece Dłubni metodą diagnostyki jednoetapowej. Prz. Nauk. Inż. Kszt. Środ. 61, 290-300.

Michalec, B., Cupak, A., Tarnawski, M., Wałęga, A. (2017). Ocena stanu technicznego jazu w Szczyglicach na rzece Rudawie. Acta Sci. Pol. Formatiom Circumiectus, 16(4), 5-12

Novak, P., Moffat, A.I.B., Nalluri, C., Narayanan, R. (2007). Hydraulic Structures. London: Taylor \& Francis.

Przedwojski, B., Kałuża, T., Zawadzki, P. (2007). Analiza układu zwierciadła wody rzeki Warty na odcinku Poznań- skiego Węzła Wodnego. Umowa nr 22/2007/U z Urzędem Miasta Poznania, Wydziałem Urbanistyki i Architektury, maszynopis Katedra Budownictwa Wodnego AR, Poznań.

Radecki-Pawlik, A., Radecki-Pawlik, B., Podkanowicz, P.,Plesiński, K. (2018). Rip-rap revetment exploitation and designing problems: the Czarny Dunajec river case study. Acta Scientiarum Polonorum. Formatio Circumiectus, 17(1), 175.

Szpikowski, J., Domańska, M. (2014). Wpływ uwarunkowań geomorfologicznych i antropogenicznych na stan hydromorfologiczny górnej Parsęty. Monitoring Środowiska Przyrodniczego, 16, 65-74.

RCC (2014). Manual of River Restoration Technique. The River Restoration Centre, Cranfield University, Wielka Brytania. http://www.therrc.co.uk/manual-river-restoration-techniques.

Tarnawski M., Michalec B. (2007). Ocena stanu technicznego i określenie możliwości przeprowadzenia wód wezbraniowych przez jaz na rzece Usznicy. Infrastr. Ekol. Ter. Wiejs., 4/2, 189-199.

Tymiński T., Kałuża T. (2012). Investigation of Mechanical Properties and Flow Resistance of Flexible Riverbank Vegetation. Polish Journal of Environmental Studies. $21,1,201-207$

Tymiński T., Kałuza T. (2013). Effect of vegetation on flow conditions in the "nature-like" fishways. Rocznik Ochrona Srodowiska, 15,1, 348-360.

TU Deflt (2007). Design of river and canal structures. The rock manual. Virtual Knowledge Centre-Hydraulic Engineering, Delft University of Technical. http://www. kennisbank-waterbouw.nl/DesignCodes/rockmanual/ chapter\%208.pdf.

Walczak, N., Zawadzki, P., Walczak, Z., Hämmerling, M., Szymczak-Graczyk, A. (2017): Ocena stanu technicznego jazu i umocnień na przykładzie Jeziora Maltańskiego w Poznaniu. Gospodarka Wodna 12, 419-424.

Walczak, N., Walczak, Z., Kałuża, T., Hämmerling, M., Stachowski, P. (2018). The Impact of Shrubby Floodplain Vegetation Growth on the Discharge Capacity of River Valleys. Water, 10(5), 556.

Wołoszyn, J., Czamara, W., Eliasiewicz, R., Krężel, J. (1994). Regulacja rzek i potoków. Wrocław: Wydawnictwo Akademii Rolniczej we Wrocławiu.

Zawadzki, P. (2005). Stan techniczny jazów na terenie miasta Poznaniu. Roczniki Akademii Rolniczej w Poznaniu CCCLXV, Melioracje i Inżynieria Środowiska 26, Wydawnictwo Akademii Rolniczej im. Augusta Cieszkowskiego w Poznaniu, 535-544.

Żelazo, J., Popek, Z. (2002). Podstawy renaturyzacji rzek. Warszawa: Wydawnictwo SGGW. 


\section{OCENA STANU TECHNICZNEGO UMOCNIEŃ BRZEGÓW CIEKÓW I ZBIORNIKÓW NA TERENIE MIASTA POZNANIA}

\section{ABSTRAKT}

\section{Cel pracy}

W prezentowanej publikacji oceniono stan techniczny umocnień na następujących obiektach: rzeki Warty, Cybiny, Jeziora Maltańskiego, Jeziora Rusałka, rzeki Bogdanki, Stawów Sołackich oraz rzeki Głównej.

\section{Materiat i metody}

Brzegi rzek i zbiorników wodnych na terenie miast wymagają szczególnej uwagi. Naturalne procesy (akumulacja osadów, spływy powierzchniowe, filtracja wód gruntowych) oraz działanie człowieka (w tym również bezmyślne akty wandalizmu) wymuszają potrzebę ciągłego monitorowania brzegów oraz podejmowanie celowych działań zapewniających bezpieczeństwo ich użytkownika. Odpowiednio zaprojektowane, wykonane i utrzymane umocnienia pozwalają na długotrwałe zabezpieczenie skarp przed zniszczeniami oraz bezpieczny dostęp do wody mieszkańcom miasta. W Poznaniu dostęp do brzegów Warty i jej dopływów jest nieograniczony. Wzdłuż cieków powstały ścieżki spacerowe i rowerowe. Wody płynących rzek zostały spiętrzone, a atrakcją parków stały się zbiornik wodne. Największy sztuczny zbiornik Jeziora Maltańskiego na rzece Cybina, na którym powstał tor regatowy i kąpielisko, użytkowany jest w warunkach silnej antropopresji. Trybuny toru regatowego i jego zaplecze techniczne wykorzystywane są przy organizacji masowych imprez przez wielotysięczny tłum sympatyków sportów wodnych. Od pierwszych ciepłych wiosennych dni brzegi Warty na śródmiejskim odcinku rzeki okupowane są przez poznaniaków. Otwarte przy 4 plażach miejskich wypożyczalnie sprzętu pływającego oferują kajaki i łodzie z napędem motorowym.

\section{Wyniki i wnioski}

Ogólny stan umocnień inwentaryzowanych brzegów rzek i zbiorników wodnych należy ocenić jako dobry. Najniższą ocenę, stan zadawalający, uzyskały umocnienia elastyczne w postaci narzutu kamiennego.

Stowa kluczowe: budowla hydrotechniczna, stan techniczny, umocnienia 